\title{
Natural resistance of soybean cultivars to the soybean looper larva Chrysodeixis includens (Lepidoptera: Noctuidae)
}

\author{
Paulo Eduardo Wille ${ }^{(1)}$, Bruna Angelina Pereira(1), Cleiton Luiz Wille(1), Samanta Souza Restelatto(1), \\ Mari Inês Carissimi Boff( ${ }^{(1)}$ and Cláudio Roberto Franco ${ }^{(1)}$
}

\begin{abstract}
(1)Universidade do Estado de Santa Catarina, Centro de Ciências Agroveterinárias, Departamento de Agronomia, Avenida Luiz de Camões, no 2.090, Conta Dinheiro, CEP 88520-000 Lages, SC, Brazil. E-mail: pauloewille@gmail.com, bru.pereira@yahoo.com.br, cleitonwille@gmail.com, restelatto_sam@hotmail.com, mari.boff@udesc.br, claudio.franco@udesc.br
\end{abstract}

\begin{abstract}
The objective of this work was to evaluate the natural resistance of soybean cultivars to Chrysodeixis includens. For this, four commercial soybean cultivars recommended for the Southern region of Brazil were used: BR 36, NA 5909 RG, BMX Turbo RR, and Benso 1RR. In the laboratory, larvae were subjected to the antixenosis feeding assay, in which they were free or not to choose among old leaves, new leaves, and pods. Neonate larvae were subjected to two antibiosis tests: in the first one, they were fed with leaves from the middle third of the plants of the four cultivars; and, in the second one, with leaves or pods of the NA 5909 RG cultivar. Chrysodeixis includens larvae prefer leaves over pods and old leaves over new ones. The Benso 1RR cultivar extends the development cycle of $C$. includens, but only BMX Turbo RR will reduce the population growth of larvae in the next generations.
\end{abstract}

Index terms: integrated pest management, IPM, lepidopteran pests, plant resistance, Plusiinae.

\section{Resistência natural de cultivares de soja à lagarta-falsa-medideira Chrysodeixis includens (Lepidoptera: Noctuidae)}

Resumo - O objetivo deste trabalho foi avaliar a resistência natural de cultivares de soja a Chrysodeixis includens. Para tanto, utilizaram-se quatro cultivares comerciais de soja recomendadas para a região Sul do Brasil: BR 36, NA 5909 RG, BMX Turbo RR e Benso 1RR. No laboratório, as lagartas foram submetidas ao ensaio de antixenose de alimentação, com e sem chance de escolha por folhas velhas, folhas novas e vagens. Já as lagartas neonatas foram submetidas a dois testes de antibiose: no primeiro, foram alimentadas com folhas do terço médio de plantas das quatro cultivares; e, no segundo, com folhas ou vagens da cultivar NA 5909 RG. As lagartas de $C$. includens preferem folhas a vagens e folhas velhas a novas. A cultivar Benso 1RR prolonga o ciclo de desenvolvimento de C. includens, mas apenas BMX Turbo RR reduzirá o crescimento populacional das larvas nas próximas gerações.

Termos para indexação: manejo integrado de pragas, MIP, lepidópteros-praga, resistência de plantas, Plusiinae.

\section{Introduction}

The soybean [Glycine $\max (\mathrm{L}$.$) Merrill] crop has a$ prominent position in the Brazilian economy, with an annual output exceeding 95 million tons. Therefore, compared with other countries, Brazil is positioned as the second largest producer of soybean, accounting for approximately $30 \%$ of global production (Campos, 2010; Usda, 2016).

The significant socioeconomic importance of soybean has promoted an increased demand for highyield grain cultivars. However, soybean production is limited by several factors, especially pest insects that can cause significant losses, particularly in the absence of control measures (Carvalho et al., 2012; HoffmannCampo et al., 2012; Oliveira et al., 2014).
In Argentina, Brazil, Chile, and Uruguay, 69 species of the order Lepidoptera have been associated with the soybean crop (Formentini et al., 2015). The majority of the larvae are considered defoliators, such as the velvetbean caterpillar Anticarsia gemmatalis Hübner, 1818, and the soybean looper Chrysodeixis includens Walker, 1858. However, some species, including those of the genera Spodoptera, Helicoverpa, and Heliothis, can also damage the pods by feeding on them (Santos et al., 2010; Hoffmann-Campo et al., 2012; Formentini et al., 2015); these injuries to the pods reduce soybean grain yield and quality (Rogers \& Brier, 2010; Shankar et al., 2014).

During recent years, $C$. includens has been considered a primary pest in Brazil, mainly due 
to its: occurrence in all states of the country; high polyphagia, with 175 species of host plants; and resistance to control measures, such as the application of insecticides, which can be explained by the habit of the species taking shelter in the middle and lower thirds of the plant (Hoffmann-Campo et al., 2012; Baldin et al., 2014; Specht et al., 2015). The incorrect use of insecticides and fungicides on soybean has also been identified as a factor that has contributed to the increase of this insect population, particularly by contributing to a high mortality of biological control agents (Sosa-Gómez et al., 2010).

An alternative control measure is the use of plants that are naturally resistant to insects and that can be used for the management of $C$. includens in soybean (Rose et al., 1989; Piubelli et al., 2005) and dry bean (Morando et al., 2015), as well as of other lepidopteran pests species affecting the soybean crop, such as A. gemmatalis (Fugi et al., 2005), Spodoptera cosmioides Walker, 1858 (Boiça Júnior et al., 2015), and S. eridania Cramer, 1782 (Favetti et al., 2015). This control method allows reducing insect populations to levels that do not cause economic damages to plants, avoiding ecological imbalances and accumulative waste in the environment and foods (HoffmannCampo et al., 2012).

Cultivars that slow the development of insect pests or adversely affect their biological variables also extend their exposure to abiotic and biotic environmental adversities, such as natural parasitism in the field (Bürgi $\&$ Mills, 2013). An additional possible advantage is the reduction of the need for insecticide application during the crop cycle in the field, lowering environmental contamination (Hoffmann-Campo et al., 2012).

The objective of this work was to evaluate the natural resistance of soybean cultivars to Chrysodeixis includens.

\section{Materials and Methods}

Three experiments with four commercial soybean cultivars recommended for the Southern region of Brazil were conducted in a climate chamber, in a laboratory, at $25 \pm 2{ }^{\circ} \mathrm{C}, 60 \pm 10 \%$ relative humidity, and 14-hour photophase, consisting of one feeding antixenosis assay and two antibiosis assays.

In a greenhouse, seeds of the BR 36, NA 5909 RG, BMX Turbo RR, and Benso 1RR cultivars were sown in $3.5-\mathrm{L}$ pots, containing gardening substrate and soil (1:1), and were fertilized as recommended for the crop. In order to avoid possible interferences to larvae feeding, no pesticides were applied during the cultivation of the plants.

To conduct the assays, $C$. includens larvae were collected during March 2014 from a 'NA 5909 RG' soybean crop planted on a commercial farm located in the municipality of Lages, in the state of Santa Catarina, Brazil $\left(27^{\circ} 52^{\prime} 02^{\prime \prime} \mathrm{S}, 50^{\circ} 19^{\prime} 28^{\prime \prime} \mathrm{W}\right)$. In the laboratory, larvae and adults were fed on an artificial diet and on a $10 \%$ honey/distilled water solution (w/v), respectively. Rearing was maintained in the climate chamber at $25 \pm 2{ }^{\circ} \mathrm{C}, 60 \pm 10 \%$ relative humidity, and 14-hour photophase (Panizzi \& Parra, 2009).

In the antixenosis assay, larvae were free or not (free-choice and no-choice tests, respectively) to choose among new leaves, old leaves, and pods, which were obtained from the four soybean cultivars in the R5 growth stage, i.e., at the beginning of seed filling (Fehr \& Caviness, 1977). New leaves were collected from the upper third of the plant, which was not fully distended; old leaves were collected from the lower third of the plant, which was distended and not senescent; and pods were collected from the whole plant. The leaf samples were collected in the form of discs, each with $2.24 \mathrm{~cm}$ in diameter. Two and four leaf discs were provided per replicate and per cultivar for the free and no-choice tests, respectively, whereas one pod per replicate and per cultivar was used in both tests.

In the free-choice test, new leaves, old leaves, and pods of each cultivar were randomly selected and placed equidistantly from each other. All plant structures were fixed above a filter paper moistened with distilled water, in the interior of a glass Petri dish $(30 \times 2 \mathrm{~cm})$, which was filled with solid paraffin. Four fifth-instar larvae were placed inside each dish. A total of 15 replicates were performed for each treatment, and each replicate consisted of one Petri dish.

For the no-choice test, each plant structure, i.e., new leaf, old leaf, or pod, was placed inside a $145-\mathrm{mL}$ plastic container above a filter paper moistened with distilled water, in order to maintain leaf turgor. In each replicate, one fourth-instar larva was transferred to a plant, totaling 30 replicates per treatment.

After 24 hours of larval feeding in both tests, leaf area and weight of the remaining pods were measured, respectively, using a leaf area meter, model LI 3000A (Li-Cor, Lincoln, NE, USA) and an analytical balance, 
model AY220 (Shimadzu do Brasil, Barueri, SP, Brazil). Subsequently, the percentage consumption by larvae was calculated by comparing the provided structures (leaf area and pod weight) with 15 replicates that were maintained under identical environmental conditions, but without the presence of larvae. These replicates were carried out to calculate the leaf area and pod weight of the structures provided in this test.

Two antibiosis assays were also conducted. During the first one, leaves were collected from the middle third of the soybean plant, without distinguishing between new and old ones. The leaves were detached from the four evaluated cultivars after the R2 phenological stage, i.e., full bloom (Fehr \& Caviness, 1977). Leaf discs with $2.24 \mathrm{~cm}$ in diameter were supplied to neonate larvae ( $<24$ hours old) individually in $145-\mathrm{mL}$ plastic containers lined with filter paper previously moistened with distilled water. For each cultivar, 100 replicates were performed. Twenty-five replicates for each cultivar, maintained under identical environmental conditions, did not receive any insects and served as a control.

Assessments were performed daily during early morning until the insects reached the pre-pupal stage. During each evaluation day, the numbers of live larvae were counted, the food remains were removed, and new leaf discs were added. From the collected data, the durations of larval and pupal stages, larval and pupal mortality, egg-to-adult duration, weight of 13-day-old larvae, leaf consumption during the larval stage, weight of pupae at 24 hours of age, and pupae deformation were calculated, according to Panizzi \& Parra (2009).

To determine leaf consumption, the food remains and leaf discs of the control were deposited separately in paper bags according to replicate and treatment. After the end of the larval stage, the leaf discs were dried in an oven with forced-air circulation, at $60^{\circ} \mathrm{C}$, for three days, in order to obtain dry weight $(\mathrm{g})$. The dry weight was then transformed into area $\left(\mathrm{cm}^{2}\right)$ by using the difference between the weight of the control leaves and of the leaf remains, as proposed by Castro et al. (2008).

During adulthood, the insects were grouped into pairs of males and females, with up to one day apart, in a $10 \times 20-\mathrm{cm}$ polyvinyl chloride (PVC) tube lined internally with a white paper sheet for moth oviposition. The insects were supplied with $10 \%$ honey/distilled water solution $(\mathrm{w} / \mathrm{v})$. Evaluations of male and female longevities, number of eggs per female, and embryonic duration of eggs were performed daily. The biological variables obtained were used to construct a life table that estimated the variables intrinsic rate of increase, net reproductive rate, mean generation time, doubling time, and finite rate of increase (Maia et al., 2000).

The second antibiosis assay was established to verify the effect of $C$. includens larvae on the leaves and pods of the NA 5909 RG cultivar. The treatments consisted of: leaves throughout the entire larval stage (leaves); pods throughout the entire larval stage (pods); leaves plus pods from the fifth instar (leaves+pods); and leaves replaced by pods from the fifth instar (leaves/ pods).

The soybean plant structures of each treatment were placed inside $145-\mathrm{mL}$ plastic containers lined with filter paper previously moistened with distilled water, with 100 replicates per treatment. The leaves and pods were provided from the middle third of the plants in the R5 growth stage. For the leaf treatment, each replicate began with one leaf, then new leaves were added and senescent leaves were removed daily. For the pod treatment, one pod was added per replicate, and pods were replaced as consumption was noted. Daily evaluations were used to determine larval stage, larval mortality, larval weight at 13 days of age, and weight of pupa at 24 hours of age.

For the feeding antixenosis assay, the data were subjected to analysis of variance (Anova) by the F-test, in a factorial design of four cultivars $\times$ three plant structures. Means were compared by Tukey's test and by linear contrast between leaf $\times$ pod and old leaf $\times$ new leaf $(\mathrm{p}>0.01)$.

For both antibiosis assays, data were transformed using $(\mathrm{x}+1)^{0.5}$ and subjected to Anova, whereas means were compared by Tukey's test, at $1 \%$ probability. When the variables did not show a normal distribution regarding larval and pupal mortality and pupae deformation, the data were subjected to the nonparametric, chi-squared $\left(\chi^{2}\right)$ Kruskal-Wallis test. Statistical analyzes were performed using the SAS software, version 9.0 (SAS Institute Inc., Cary, NC, USA).

\section{Results and Discussion}

The antixenosis assay showed that $C$. includens larvae differed regarding consumption of soybean leaves and pods, when compared by linear contrast, in 
the free-choice test $(\mathrm{F}=104.19 ; \mathrm{df}=11,168 ; \mathrm{p}=0.0001)$ and in the no-choice test $(\mathrm{F}=664.70$; $\mathrm{df}=11,348$; $\mathrm{p}=0.0001)$. In this analysis, the lowest consumption by larvae occurred in the pods (Table 1).

Differences in larval consumption of old and new leaves, also compared by linear contrast, were evident in the free-choice $(\mathrm{F}=56.92 ; \mathrm{df}=11,168 ; \mathrm{p}=0.0001)$ and in the no-choice $(\mathrm{F}=10.21 ; \mathrm{df}=11,348 ; \mathrm{p}=0.0015)$ tests. In this case, the lowest larval consumption was of new leaves (Table 1).

Interactions between soybean cultivars and plant structures were verified both in the free-choice test $(\mathrm{F}=104.19 ; \mathrm{df}=11,168 ; \mathrm{p}=0.0001)$ and in the no-choice test $(\mathrm{F}=664.70 ; \mathrm{df}=11,348 ; \mathrm{p}=0.0001)$. The least consumed old leaves were those from NA $5909 \mathrm{RG}$ and Benso 1RR in the free-choice test among cultivars (Table 1); however, no differences were found for the consumption of old leaves in the no-choice test.

Feeding on soybean pods did not exceed an average of $5.6 \%$ of the weight of the provided pod for all cultivars in the no-choice test (Table 1). However, in approximately $50 \%$ of the soybean pods, the presence of injuries was observed. Shankar et al. (2014) pointed out that soybean pods damaged by insects could be susceptible to moisture and pathogens that affect grain quality, also reducing grain yield.

Table 1. Percentage (mean \pm standard error) of soybean (Glycine max) consumption by fifth-instar (free-choice test) and fourth-instar (no-choice test) larvae of Chrysodeixis includens fed on old leaves, new leaves, and pods under laboratory conditions $\left(25 \pm 2^{\circ} \mathrm{C}, 60 \pm 10 \%\right.$ relative humidity, and 14-hour photophase) $)^{(1)}$.

\begin{tabular}{lccc}
\hline Cultivars & Old leaf & New leaf & Pod \\
\hline & & Free-choice test \\
BMX Turbo RR & $46.7 \pm 5.70 \mathrm{aA}$ & $15.6 \pm 5.22 \mathrm{aB}$ & $0.12 \pm 0.03 \mathrm{aC}$ \\
BR 36 & $44.6 \pm 6.31 \mathrm{abA}$ & $19.4 \pm 3.57 \mathrm{aB}$ & $0.05 \pm 0.04 \mathrm{aC}$ \\
Benso 1RR & $24.3 \pm 4.37 \mathrm{bcA}$ & $9.5 \pm 3.21 \mathrm{aB}$ & $0.02 \pm 0.02 \mathrm{aC}$ \\
NA 5909 RG & $10.7 \pm 2.91 \mathrm{cA}$ & $7.6 \pm 2.62 \mathrm{aA}$ & $0.07 \pm 0.03 \mathrm{aB}$ \\
\hline CV (\%) & \multicolumn{4}{c}{54.49} \\
\hline & No-choice test \\
BMX Turbo RR & $39.1 \pm 2.94 \mathrm{aA}$ & $35.3 \pm 2.67 \mathrm{abA}$ & $1.7 \pm 0.18 \mathrm{aB}$ \\
BR 36 & $39.1 \pm 2.28 \mathrm{aA}$ & $39.4 \pm 1.87 \mathrm{aA}$ & $2.4 \pm 0.19 \mathrm{aB}$ \\
Benso 1RR & $33.9 \pm 1.90 \mathrm{aA}$ & $28.2 \pm 2.30 \mathrm{bA}$ & $2.5 \pm 1.27 \mathrm{aB}$ \\
NA 5909 RG & $35.6 \pm 2.41 \mathrm{aA}$ & $26.8 \pm 2.06 \mathrm{bA}$ & $5.6 \pm 1.89 \mathrm{aB}$ \\
\hline CV (\%) & \multicolumn{3}{c}{23.63} \\
\hline
\end{tabular}

(1) Means followed by equal letters, uppercase in the rows and lowercase in the columns, do not differ by Tukey's test, at $1 \%$ probability. $\mathrm{CV}$, coefficient of variation. The data were transformed by $(x+1)^{0.5}$.
The least attacked plant structures under equal conditions presented antixenosis-type resistance. Morando et al. (2015) found that C. includens also showed antixenosis for feeding and oviposition in dry bean cultivars. The authors concluded that these characteristics can be used as a tool in dry bean breeding programs to obtain cultivars resistant to insect pests.

The first antibiosis assay indicated that the greatest antibiosis effect was found for the Benso 1RR cultivar when compared with BR 36, NA 5909 RG, and BMX Turbo RR, delaying the larval stage of $C$. includens. That cultivar also showed the longest larval stage, resulting in an increase of $8.8 \%$ in larval duration $(\mathrm{F}=16.33 ; \mathrm{df}=3,245 ; \mathrm{p}=0.0001)$ and of $5.6 \%$ in eggadult duration $(\mathrm{F}=15.32 ; \mathrm{df}=3,174 ; \mathrm{p}=0.0001)$, in comparison with the average of the other cultivars. The duration of the pupal stage, which was between 7.5 and 7.7 days $(F=0.56 ; \mathrm{df}=3,174 ; \mathrm{p}=0.6390)$ (Table 2), and the percentage of pupae deformation, which was between 7.8 and $20.6 \%\left(\chi^{2}=4.62 ; \mathrm{df}=3 ; \mathrm{p}=0.2019\right)$, were not affected; however, there was a difference in pupae mortality, which varied between 8.5 and $53.7 \%$ $\left(\chi^{2}=17.38 ; \mathrm{df}=3 ; \mathrm{p}=0.0006\right)$

The larvae that fed on the Benso 1RR cultivar showed an increased foliar consumption of $3.9 \%$ $(\mathrm{F}=20.47 ; \mathrm{df}=3,266 ; \mathrm{p}=0.0001)$ compared with the average of the other cultivars. However, the lowest weights of larvae, with reduction of $14.5 \%(F=25.29$; $\mathrm{df}=3,302 ; \mathrm{p}=0.0001)$, and of pupae, with reduction of $12.5 \%(\mathrm{~F}=28.98 ; \mathrm{df}=3,239 ; \mathrm{p}=0.0001)$, were also observed for this cultivar (Table 2).

While evaluating $C$. includens feeding on different plant hosts, Andrade et al. (2016) reported that the consumption of soybean leaves was of $141.4 \mathrm{~cm}^{2}$ until the complete larval stage, which is similar to the result found in the present study. According to Bueno et al. (2011), soybean leaf consumption by $C$. includens varied among cultivars, ranging between 63.9 and 92.7 $\mathrm{cm}^{2}$, less than the values found in the present study.

No significant difference was observed regarding larvae mortality, which ranged from 36 to $42 \%$ $\left(\chi^{2}=1.40 ; \mathrm{df}=3 ; \mathrm{p}=0.7046\right)$. When studying C. includens in soybean, Andrade et al. (2016) found larval mortality of $15 \%$, different from the value estimated in the present study, proving the antibiosis effect on the tested cultivars. 
The following biological variables of the adult insect did not differ according to the cultivar provided at the larval stage: pre-oviposition duration $(\mathrm{F}=0.26$; $\mathrm{df}=3,34 ; \mathrm{p}=0.8378)$, average number of eggs per female $(\mathrm{F}=0.11 ; \mathrm{df}=3,24 ; \mathrm{p}=0.5440)$, embryonic duration of eggs ( $3 \pm 0$ days), male longevity $(\mathrm{F}=1.01 ; \mathrm{df}=3,36$; $\mathrm{p}=0.4015)$, and female longevity $(\mathrm{F}=4.04 ; \mathrm{df}=3,36$; $\mathrm{p}=0.0142$ ).

Favetti et al. (2015) evaluated the biology of $S$. eridania in four soybean cultivars and also found differences in the duration of the larval stage, as well as of the pupal stage; however, no differences in pre-oviposition duration, number of eggs, and male and female longevity. Fugi et al. (2005) also observed a reduction in the larval stage of $A$. gemmatalis among soybean cultivars; however, contrary to Favetti et al. (2015), the authors reported differences related to female longevity, number of eggs, and egg stage duration.

Specht et al. (2016) assessed the reproduction potential of $S$. eridania in soybean and noticed that the number of copulated females was not affected by the size of pupae; however, differences were observed while analyzing egg fertility and adult longevity.

Souza et al. (2014) studied ten soybean cultivars and found that the duration and survival rate of the larval stage, the duration of the pupal stage, cycle duration, and larval weight were the main biological variables that contributed to the evaluation of the antibiosis effect on S. eridania. In the present study, the same evaluated variables also played an important role in determining the effect of soybean antibiosis on C.includens.

The increase in the larval stage and, therefore, in the egg-adult duration, was associated with a larger amount of food for the insect to complete its development. This can be explained by the presence of any compound that is toxic to the larva, such as coumestrol (Rose et al., 1989) and flavonoids, including rutin and genistein (Piubelli et al., 2005).

According to Souza et al. (2014), the PI 227687 and PI 227682 soybean cultivars expressed high antibiosis effects on S. eridania, and IAC 100 and DM 339 were found to provide moderate resistance, extending the life cycle of this insect. Boiça Júnior et al. (2015) also observed that the Dowling cultivar extended the duration of the larval stage of $S$. cosmioides, which was considered as an indicative of low-quality food.

The life table showed differences only for the BMX Turbo RR cultivar, which were related to the variables net reproductive rate $(\mathrm{p}=0.039)$ and finite rate of increase $(p=0.037)$, suggesting that, over the next generations, this cultivar will slow the development of $C$. includens larvae (Table 3). While evaluating biological parameters of $C$. includens larvae in soybean, Moonga \& Davis (2016) detected similar results, with net reproductive rate varying from 2.6 to 55 .

The second antibiosis assay with the NA 5909 RG cultivar showed that when the only source of food provided was soybean pods (pod treatment), the larvae were not able to reach the second instar as they experienced $100 \%$ mortality (Table 4); the

Table 2. Biological variables of the immature stage (mean \pm standard error) and leaf average consumption (LAC) (mean \pm standard error) of Chrysodeixis includens larvae fed on leaves of four soybean (Glycine max) cultivars under laboratory conditions $\left(25 \pm 2{ }^{\circ} \mathrm{C}, 60 \pm 10 \% \text { relative humidity, and 14-hour photophase }\right)^{(1)}$.

\begin{tabular}{|c|c|c|c|c|c|c|}
\hline \multirow[t]{2}{*}{ Cultivar } & \multicolumn{3}{|c|}{ Duration (days) } & \multicolumn{2}{|c|}{ Weight (g) } & \multirow{2}{*}{$\begin{array}{l}\mathrm{LAC} \\
\left(\mathrm{cm}^{2}\right)\end{array}$} \\
\hline & Larva & Egg-adult & Pupa & Larva & Pupa & \\
\hline Benso 1RR & $\begin{array}{c}22.2 \pm 0.28 \mathrm{a} \\
(\mathrm{n}=64)\end{array}$ & $\begin{array}{c}29.7 \pm 0.36 a \\
(n=41)\end{array}$ & $\begin{array}{c}7.6 \pm 0,08 a \\
(n=41)\end{array}$ & $\begin{array}{c}0.1455 \pm 0.01 b \\
(n=79)\end{array}$ & $\begin{array}{c}0.1778 \pm 0.01 \mathrm{c} \\
(\mathrm{n}=63)\end{array}$ & $\begin{array}{c}198.6 \pm 1.71 a \\
(n=69)\end{array}$ \\
\hline BMX Turbo RR & $\begin{array}{c}20.1 \pm 0.24 b \\
(n=58)\end{array}$ & $\begin{array}{c}27.6 \pm 0.33 b \\
(n=37)\end{array}$ & $\begin{array}{c}7.7 \pm 0,09 a \\
(n=37)\end{array}$ & $\begin{array}{c}0.2223 \pm 0.01 \mathrm{a} \\
(\mathrm{n}=77)\end{array}$ & $\begin{array}{c}0.2170 \pm 0.00 \mathrm{a} \\
(\mathrm{n}=58)\end{array}$ & $\begin{array}{c}190.9 \pm 1.52 b \\
(n=69)\end{array}$ \\
\hline BR 36 & $\begin{array}{c}19.9 \pm 0.15 b \\
(n=60)\end{array}$ & $\begin{array}{c}27.8 \pm 0.18 b \\
(n=47)\end{array}$ & $\begin{array}{c}7.7 \pm 0,07 a \\
(n=47)\end{array}$ & $\begin{array}{c}0.2300 \pm 0.01 \mathrm{a} \\
(\mathrm{n}=77)\end{array}$ & $\begin{array}{c}0.2169 \pm 0.01 \mathrm{a} \\
\quad(\mathrm{n}=58)\end{array}$ & $\begin{array}{c}190.1 \pm 0.86 b c \\
(n=65)\end{array}$ \\
\hline NA 5909 RG & $\begin{array}{c}19.4 \pm 0.46 b \\
(n=67)\end{array}$ & $\begin{array}{c}27.4 \pm 0.19 b \\
(n=53)\end{array}$ & $\begin{array}{c}7.5 \pm 0,16 a \\
(n=53)\end{array}$ & $\begin{array}{c}0.2336 \pm 0.01 \mathrm{a} \\
(\mathrm{n}=71)\end{array}$ & $\begin{array}{c}0.2008 \pm 0.00 b \\
(n=64)\end{array}$ & $\begin{array}{c}184.7 \pm 0.48 \mathrm{c} \\
(\mathrm{n}=67)\end{array}$ \\
\hline $\mathrm{CV}(\%)$ & 12.21 & 6.23 & 10,08 & 3.06 & 1.12 & 5.43 \\
\hline
\end{tabular}

${ }^{(1)}$ Means followed by equal letters in the columns do not differ by Tukey's test, at $1 \%$ probability. For the analysis, the data were transformed by $(\mathrm{x}+1)^{0.5}$. $\mathrm{CV}$, coefficient of variation; and $\mathrm{n}$, number of insects. 
average duration of survival in this treatment was only of 2.1 days. In the treatment in which the leaves were replaced by pods from the fifth instar (leaf/ pod treatment), an increase of $15 \%$ was observed in the larval stage, in comparison with the shortest one $(\mathrm{F}=29.35 ; \mathrm{df}=2,265 ; \mathrm{p}=0.0001)$.

The obtained result confirms the feeding antixenosis assay, in which the insect showed lower consumption of pods (Table 1). It is possible that the increases in development duration and particularly mortality rate are linked to nutritional characteristics such as biocide effects, low nutrient availability, or low palatability. As these characteristics prevented the continuity of larval development, resistance can be classified as of the antixenosis or even antibiosis type (Panizzi \& Parra, 2009).

At the beginning of the fifth instar when pods were added (leaf + pod treatment), no difference was observed in larval development when compared with the treatment in which only leaves were provided (leaf treatment) (Table 4). However, $10.8 \%$ of the pods offered to the larvae were injured due to herbivory, indicating that those pods were bitten during the food selection process.

In the evaluations of larval $(\mathrm{F}=98.95 ; \mathrm{df}=2,229$; $\mathrm{p}=0.0001)$ and pupal $(\mathrm{F}=12.29 ; \mathrm{df}=2,103$; $p=0.0001$ ) weights, the lowest averages were observed in the leaf/pod treatment, with reductions of up to 61 and $17 \%$, respectively, in comparison with the leaf treatment (Table 5). However, no differences were verified between the leaf and leaf + pod treatments regarding larval and pupal weights.

Chrysodeixis includens is known as a species that only defoliates soybean; however, other larvae species, such as Spodoptera spp., can also feed on pods (Formentini et al., 2015). Santos et al. (2010) concluded that even though S. eridania and S. cosmioides can feed on different cotton (Gossypium hirsutum L.) structures, their survival is highly dependent on the type of food. These authors found that the average larval survival

Table 3. Fertility life table of Chrysodeixis includens on four soybean (Glycine max) cultivars under laboratory conditions $\left(25 \pm 2{ }^{\circ} \mathrm{C}, 60 \pm 10 \% \text { relative humidity, and 14-hour photophase }\right)^{(1)}$.

\begin{tabular}{lccccc}
\hline Treatment & $\mathrm{R}_{\mathrm{o}}$ & $\mathrm{T}$ & $\mathrm{DT}$ & $\mathrm{r}_{\mathrm{m}}$ & $\lambda$ \\
\hline BR 36 & $22.2 \pm 8.97 \mathrm{a}$ & $30.6 \pm 0.65 \mathrm{a}$ & $6.4 \pm 1.28 \mathrm{a}$ & $0.10 \pm 0.016 \mathrm{a}$ & $1.10 \pm 0.018 \mathrm{a}$ \\
NA 5909 RG & $8.3 \pm 3.88 \mathrm{a}$ & $31.7 \pm 1.17 \mathrm{a}$ & $8.9 \pm 3.20 \mathrm{a}$ & $0.07 \pm 0.017 \mathrm{a}$ & $1.01 \pm 0.178 \mathrm{a}$ \\
BMX Turbo RR & $4.6 \pm 1.95 \mathrm{~b}$ & $30.0 \pm 0.66 \mathrm{a}$ & $10.8 \pm 5.32 \mathrm{a}$ & $0.05 \pm 0.016 \mathrm{a}$ & $1.05 \pm 0.017 \mathrm{~b}$ \\
Benso 1RR & $28.8 \pm 17.95 \mathrm{a}$ & $30.6 \pm 1.51 \mathrm{a}$ & $5.1 \pm 2.19 \mathrm{a}$ & $0.12 \pm 0.030 \mathrm{a}$ & $1.12 \pm 0.033 \mathrm{a}$ \\
\hline
\end{tabular}

${ }^{(1)}$ Means followed by equal letters in the columns do not differ by the jackknifing test, at $5 \%$ probability. $\mathrm{R}_{\mathrm{o}}$, net reproductive rate; $\mathrm{T}$, mean generation time; DT, doubling time; $r_{m}$, intrinsic rate of increase; and $\lambda$, finite rate of increase.

Table 4. Duration of the larval stage (mean \pm standard error) of Chrysodeixis includens in leaves and pods of the soybean (Glycine max) cultivar NA 5909 RG under laboratory conditions $\left(25 \pm 2^{\circ} \mathrm{C}, 60 \pm 10 \%\right.$ relative humidity, and 14 -hour photophase) $)^{(1)}$.

\begin{tabular}{|c|c|c|c|c|c|c|c|c|}
\hline \multirow[t]{2}{*}{ Treatment $^{(2)}$} & \multicolumn{8}{|c|}{ Insect development stage (days) } \\
\hline & $1^{\circ}$ & $2^{\circ}$ & $3^{\circ}$ & $4^{\circ}$ & $5^{\circ}$ & $6^{\circ}$ & Pre-pupa & Larva \\
\hline Leaves & $\begin{array}{c}2.2 \pm 0.01 \mathrm{a} \\
(\mathrm{n}=100)\end{array}$ & $\begin{array}{c}2.0 \pm 0.01 \mathrm{a} \\
(\mathrm{n}=95)\end{array}$ & $\begin{array}{c}1.8 \pm 0.02 \mathrm{a} \\
(\mathrm{n}=95)\end{array}$ & $\begin{array}{c}1.7 \pm 0.03 a \\
(n=95)\end{array}$ & $\begin{array}{c}2.1 \pm 0.02 b \\
(n=92)\end{array}$ & $\begin{array}{c}3.8 \pm 0.02 b \\
(n=82)\end{array}$ & $\begin{array}{c}1.65 \pm 0.02 \mathrm{ab} \\
(\mathrm{n}=69)\end{array}$ & $\begin{array}{c}17.1 \pm 0.02 b \\
(n=69)\end{array}$ \\
\hline Pods & - & - & - & - & - & - & - & - \\
\hline Leaves+Pods & $\begin{array}{c}2.2 \pm 0.02 \mathrm{a} \\
(\mathrm{n}=100)\end{array}$ & $\begin{array}{c}2.2 \pm 0.02 \mathrm{a} \\
(\mathrm{n}=95)\end{array}$ & $\begin{array}{c}1.9 \pm 0.02 a \\
(n=93)\end{array}$ & $\begin{array}{c}1.8 \pm 0.03 a \\
(n=93)\end{array}$ & $\begin{array}{c}2.2 \pm 0.03 b \\
\quad(n=92)\end{array}$ & $\begin{array}{c}3.4 \pm 0.02 b \\
(n=83)\end{array}$ & $\begin{array}{c}1.9 \pm 0.02 \mathrm{a} \\
(\mathrm{n}=75)\end{array}$ & $\begin{array}{c}17.5 \pm 0.02 b \\
(n=75)\end{array}$ \\
\hline Leaves/Pods & $\begin{array}{c}2.4 \pm 0.03 \mathrm{a} \\
(\mathrm{n}=100)\end{array}$ & $\begin{array}{c}2.3 \pm 0.03 \mathrm{a} \\
(\mathrm{n}=90)\end{array}$ & $\begin{array}{c}2.0 \pm 0,02 \mathrm{a} \\
(\mathrm{n}=88)\end{array}$ & $\begin{array}{c}1.9 \pm 0.03 \mathrm{a} \\
(\mathrm{n}=86)\end{array}$ & $\begin{array}{c}3.2 \pm 0.04 \mathrm{a} \\
(\mathrm{n}=84)\end{array}$ & $\begin{array}{c}5.6 \pm 0.07 \mathrm{a} \\
(\mathrm{n}=21)\end{array}$ & $\begin{array}{c}1.4 \pm 0.06 b \\
(n=12)\end{array}$ & $\begin{array}{c}19.6 \pm 0.06 a \\
(n=12)\end{array}$ \\
\hline $\mathrm{CV}(\%)$ & 9.46 & 8.53 & 9.13 & 12.71 & 12.31 & 7.81 & 8.38 & 3.14 \\
\hline
\end{tabular}

${ }^{(1)}$ Means followed by equal letters in the columns do not differ by Tukey's test, at $1 \%$ probability. For the analysis, the data were transformed by $(\mathrm{x}+1)^{0.5}$. ${ }^{(2)}$ Leaves, leaves throughout the larval cycle; Pods, pods throughout the larval cycle; Leaves+Pods, leaves plus pods from the fifth instar; and Leaves/ Pods, leaves replaced by pods from the fifth instar. CV, coefficient of variation; and n, number of insects. 
Table 5. Average larval and pupal weights (mean \pm standard error) of Chrysodeixis includens in leaves and pods of the soybean (Glycine max) cultivar NA 5909 RG under laboratory conditions $\left(25 \pm 2{ }^{\circ} \mathrm{C}, 60 \pm 10 \%\right.$ relative humidity, and 14-hour photophase) $)^{(1)}$.

\begin{tabular}{lcc}
\hline Treatment ${ }^{(2)}$ & Larval weight $(\mathrm{g})$ & Pupal weight $(\mathrm{g})$ \\
\hline Leaves & $0.2872 \pm 0.01 \mathrm{a}$ & $0.2425 \pm 0.01 \mathrm{a}$ \\
& $(\mathrm{n}=80)$ & $(\mathrm{n}=46)$ \\
Pods & - & - \\
& $0.2686 \pm 0.01 \mathrm{a}$ & $0.2560 \pm 0.01 \mathrm{a}$ \\
Leaves+Pods & $(\mathrm{n}=82)$ & $(\mathrm{n}=53)$ \\
& $0.1114 \pm 0.01 \mathrm{~b}$ & $0.2004 \pm 0.01 \mathrm{~b}$ \\
Leaves/Pods & $(\mathrm{n}=69)$ & $(\mathrm{n}=7)$ \\
& 3.42 & 1.17 \\
\hline $\mathrm{CV}(\%)$ &
\end{tabular}

(1)Means followed by equal letters in the columns do not differ by Tukey's test, at $1 \%$ probability. For the analysis, the data were transformed by $(\mathrm{x}+1)^{0.5} .{ }^{(2)}$ Leaves, leaves throughout the larval cycle; Pods, pods throughout the larval cycle; Leaves+Pods, leaves plus pods from the fifth instar; and Leaves/Pods, leaves replaced by pods from the fifth instar. CV, coefficient of variation; and $\mathrm{n}$, number of insects.

rate in different structures, i.e., leaves, floral buds, and bolls, was $>70 \%$; however, when the only structures provided were bolls, survival was $<40 \%$.

Therefore, although injuries may occur on the pod, the plant structure is not preferred by $C$. includens, negatively affecting its life cycle. This feeding antixenosis must be evaluated under field conditions, mainly to assess the real economic damage to this reproductive structure.

Considering that cultivars can slow insect development, affecting population dynamics and pest control methods, further work should be conducted on other plant resistance variables, such as oviposition antixenosis, in order to use the obtained information to recommend new cultivars or to improve soybean breeding programs (Souza et al., 2014; Boiça Júnior et al., 2015).

\section{Conclusions}

1. The soybean (Glycine max) plant structure most preferred by Chrysodeixis includens is old leaves, and larvae do not develop on pods in all tested cultivars.

2. The Benso 1RR cultivar extends the life cycle of $C$. includens, showing the lowest larval and pupal weights.

3. The variables net reproductive rate and finite rate of increase suggest that the lowest development of
C. includens in the next generations will occur in the BMX Turbo RR cultivar.

\section{Acknowledgments}

To Coordenação de Aperfeiçoamento de Pessoal de Nível Superior (Capes), for scholarship to the first author; to Dr. Alexandre Specht from Embrapa Cerrados, for assistance in confirming the species Chrysodeixis includens; and to Fundação de Amparo à Pesquisa e Inovação do Estado de Santa Catarina (Fapesc, Project No. TO 2013 TR 3395), for financial support.

\section{References}

ANDRADE, K.; BUENO, A. de F.; SILVA, D.M. da; STECCA, C. dos S.; PASINI, A.; OLIVEIRA, M.C.N. de. Bioecological characteristics of Chrysodeixis includens (Lepidoptera: Noctuidae) fed on different hosts. Austral Entomology, v.55, p.449-454, 2016. DOI: 10.1111/aen.12208.

BALDIN, E.L.L.; LOURENÇÃO, A.L.; SCHLICK-SOUZA, E.C. Outbreaks of Chrysodeixis includens (Walker) (Lepidoptera: Noctuidae) in common bean and castor bean in São Paulo State, Brazil. Bragantia, v.73, p.458-461, 2014. DOI: 10.1590/16784499.0277.

BOIÇA JÚNIOR, A.L.; BOTTEGA, D.B.; SOUZA, B.H.S. de; RODRIGUES, N.E.L.; MICHELIN, V. Determinação dos tipos de resistência a Spodoptera cosmioides (Walker) (Lepidoptera: Noctuidae) em genótipos de soja. Semina: Ciências Agrárias, v.36, p.607-618, 2015. DOI: 10.5433/1679-0359.2015v36n2p607.

BUENO, R.C.O. de F.; BUENO, A. de F.; MOSCARDI, F.; PARRA, J.R.P.; HOFFMANN-CAMPO, C.B. Lepidopteran larva consumption of soybean foliage: basis for developing multiplespecies economic thresholds for pest management decisions. Pest Management Science, v.67, p.170-174, 2011. DOI: 10.1002/ ps.2047.

BÜRGI, L.P.; MILLS, N.J. Developmental strategy and life history traits of Meteorus ictericus, a successful resident parasitoid of the exotic Light Brown Apple Moth in California. Biological Control, v.66, p.173-182, 2013. DOI: 10.1016/j.biocontrol.2013.05.006.

CAMPOS, M. de C. Expansão da soja no território nacional: o papel da demanda internacional e da demanda interna. Revista Geografares, v.8, p.1-19, 2010. DOI: 10.7147/GEO8.1295.

CARVALHO, L.C.; FERREIRA, F.M.; BUENO, N.M. Importância econômica e generalidades para o controle da lagarta falsa-medideira na cultura da soja. Enciclopédia Biosfera, v.8, p.1021-1034, 2012.

CASTRO, M. de J.P. de; SILVA, P.H.S. da; PÁDUA, L.E. de M. Atividade de extrato de Piper tuberculatum Jacq. (Piperaceae) sobre Spodoptera frugiperda (J. E. Smith). Revista Ciência Agronômica, v.39, p.437-442, 2008. 
FAVETTI, B.M.; BUTNARIU, A.R.; FOERSTER, L.A. Biology and reproductive capacity of Spodoptera eridania (Cramer) (Lepidoptera, Noctuidae) in different soybean cultivars. Revista Brasileira de Entomologia, v.59, p.89-95, 2015. DOI: 10.1016/j. rbe.2015.03.002.

FEHR, W.R.; CAVINESS, C.E. Stages of soybean development. Ames: Iowa State University of Science and Technology, 1977. 11p.

FORMENTINI, A.C.; SOSA-GÓMEZ, D.R.; PAULA-MORAES, S.V. de; BARROS, N.M. de; SPECHT, A. Lepidoptera (Insecta) associated with soybean in Argentina, Brazil, Chile and Uruguay. Ciência Rural, v.45, p.2113-2120, 2015. DOI: 10.1590/0103$8478 \mathrm{cr} 20141258$.

FUGI, C.G.Q.; LOURENÇÃO, A.L.; PARRA, J.R.P. Biology of Anticarsia gemmatalis on soybean genotypes with different degrees of resistance to insects. Scientia Agricola, v.62, p.31-35, 2005. DOI: 10.1590/S0103-90162005000100006.

HOFFMANN-CAMPO, C.B.; CORRÊA-FERREIRA, B.S.; MOSCARDI, F. (Ed.). Soja: manejo integrado de insetos e outros artrópodes-praga. Brasília: Embrapa, 2012. 859p.

MAIA, A. de H.N.; LUIZ, A.J.B.; CAMPANHOLA, C. Statistical inference on associated fertility life parameters using jackknife technique: computational aspects. Journal of Economic Entomology, v.93, p.511-518, 2000. DOI: 10.1603/0022-049393.2.511.

MOONGA, M.N.; DAVIS, J.A. Partial life history of Chrysodeixis includens (Lepidoptera: Noctuidae) on summer hosts. Journal of Economic Entomology, v.109, p.1713-1719, 2016. DOI: 10.1093/ jee/tow156.

MORANDO, R.; BALDIN, E.L.L.; CRUZ, P.L.; LOURENÇÃO, A.L.; CHIORATO, A.F. Antixenosis of bean genotypes to Chrysodeixis includens (Lepidoptera: Noctuidae). Pesquisa Agropecuária Brasileira, v.50, p.450-458, 2015. DOI: 10.1590/ S0100-204X2015000600003.

OLIVEIRA, C.M.; AUAD, A.M.; MENDES, S.M.; FRIZZAS, M.R. Crop losses and the economic impact of insect pests on Brazilian agriculture. Crop Protection, v.56, p.50-54, 2014. DOI: 10.1016/j.cropro.2013.10.022.

PANIZZI, A.R.; PARRA, J.R.P. (Ed.). Bioecologia e nutrição de insetos: base para o manejo integrado de pragas. Brasília: Embrapa Informação Tecnológica; Londrina: Embrapa Soja, 2009. 1164p.

PIUBELLI, G.C.; HOFFMANN-CAMPO, C.B.; MOSCARDI, F; MIYAKUBO, S.H.; OLIVEIRA, M.C.N. de. Are chemical compounds important for soybean resistance to Anticarsia gemmatalis? Journal of Chemical Ecology, v.31, p.1509-1525, 2005. DOI: 10.1007/s10886-005-5794-z.

ROGERS, D.J.; BRIER, H.B. Pest-damage relationships for Helicoverpa armigera (Hübner) (Lepidoptera: Noctuidae) on soybean (Glycine max) and dry bean (Phaseolus vulgaris) during pod-fill. Crop Protection, v.29, p.47-57, 2010. DOI: 10.1016/j. cropro.2009.08.015.

ROSE, R.L.; SPARKS, T.C.; SMITH, C.M. The influence of resistant soybean (PI 227687) foliage and coumestrol on the metabolism of xenobiotics by the soybean looper, Pseudoplusia includens (Walker). Pesticide Biochemistry and Physiology, v.34, p.17-26, 1989. DOI: 10.1016/0048-3575(89)90136-3.

SANTOS, K.B. dos; MENEGUIM, A.M.; SANTOS, W.J. dos; NEVES, P.M.O.J.; SANTOS, R.B. dos. Caracterização dos danos de Spodoptera eridania (Cramer) e Spodoptera cosmioides (Walker) (Lepidoptera: Noctuidae) a estruturas de algodoeiro. Neotropical Entomology, v.39, p.626-631, 2010. DOI: 10.1590/ S1519-566X2010000400025.

SHANKAR, M.; MUNGHATE, R.S.; RAMESH BABU, T.; SRIDEVI, D.; SHARMA, H.C. Population density and damage by pod borers, Helicoverpa armigera and Spodoptera exigua in a diverse array of chickpea genotypes under natural infestation in the field. Indian Journal of Entomology, v.76, p.117-127, 2014.

SOSA-GÓMEZ, D.R.; LÓPEZ LASTRA, C.C.; HUMBER, R.A. An overview of arthropod-associated fungi from Argentina and Brazil. Mycopathologia, v.170, p.61-76, 2010. DOI: 10.1007/ s11046-010-9288-3.

SOUZA, B.H.S.; SILVA, A.G.; JANINI, J.C.; BOICA JÚNIOR, A.L. Antibiosis in soybean genotypes and the resistance levels to Spodoptera eridania (Cramer) (Lepidoptera: Noctuidae). Neotropical Entomology, v.43, p.582-587, 2014. DOI: 10.1007/ s13744-014-0241-x.

SPECHT, A.; MONTEZANO, D.G.; SOSA-GÓMEZ, D.R.; PAULA-MORAES; S.V.; ROQUE-SPECHT, V.F.; BARROS, N.M. Reproductive potential of Spodoptera eridania (Stoll) (Lepidoptera: Noctuidae) in the laboratory: effect of multiple couples and the size. Brazilian Journal of Biology, v.76, p.526530, 2016. DOI: 10.1590/1519-6984.23114.

SPECHT, A.; PAULA-MORAES, S.V. de; SOSA-GÓMEZ, D.R. Host plants of Chrysodeixis includens (Walker) (Lepidoptera, Noctuidae, Plusiinae). Revista Brasileira de Entomologia, v.59, p.343-345, 2015. DOI: 10.1016/j.rbe.2015.09.002.

USDA. United States Department of Agriculture. World Agricultural Supply and Demand Estimates. Washington: Usda, 2016. p.40. (WASDE 560).

Received on May 23, 2016 and accepted on September 15, 2016 